\title{
Work-Related Variables as Correlates of Institutional Commitment of Secondary School Teachers in Cross River State, Nigeria
}

\author{
Dr. C. P. Akpan \\ Department of Educational Administration and Planning, Faculty of Education, \\ University of Calabar, Calabar, Cross River State, Nigeria
}

Email: drcpakpan@yahoo.com

\section{Doi:10.5901/mjss.2015.v6n3s1p315}

\begin{abstract}
Institutional commitment is a sort of bond between the teachers and the school they are working for and the strength of the bond depends on various work-related variables. This study therefore, was aimed at finding out the association of work-related variables, namely; staff development, working conditions and motivation with institutional commitment of teachers in secondary schools. The components of institutional commitment considered in this study were affective commitment, continuance commitment and normative commitment. The study area was Cross River State of Nigeria. Four hypotheses were formulated to guide the study. The study adopted a correlation design and stratified random sampling technique was used to select 400 teachers that constituted the sample of the study from a population of 9,764 teachers. The instrument for data collection was a 5-point Likert type questionnaire and consisted of 33 items. The data collected were analyzed using Pearson's Product Moment Correlation and multiple regression statistics. The results of the study revealed a significant positive correlation between staff development and affective commitment, continuance commitment and normative commitment. Similarly, motivation significantly related to affective commitment, continuance commitment and normative commitment. There was no significant relationship between working conditions and each component of institutional commitment of teachers. This finding indicated that working condition was not associated with teachers' commitment in secondary schools. Staff development, working conditions and motivation jointly and significantly predicted institutional commitment of teachers with motivation being the most potent contributor to the prediction. Premised on the findings of the study, it was recommended among others that the government should greatly improve the working conditions of teachers in order to enhance their commitment.
\end{abstract}

Keywords: Staff development, working conditions, motivation, institutional commitment, teachers.

\section{Introduction}

Secondary education occupies a central position in the Nigerian educational system because it is the level of education that prepares students for higher education. It is the level of education that determines the academic and professional career of students. Perhaps, it is on the basis of this understanding that the Federal Republic of Nigeria (FRN, 2013) articulates the broad aims of secondary education to include preparation of students for useful living in the society and preparation for higher education. However, the aims of secondary education in Nigeria cannot be successfully achieved without dedicated and committed teachers. This is why the issue of teacher commitment in Cross River State has attracted the attention of the public, educators and other stakeholders because "teacher commitment results in better job performance and effectiveness" (Akpan, 2013). The teachers are the hubs of every educational system and the success of any educational programme rests upon them. The crux of the matter is that there is observable poor attitude of teachers toward work in many secondary schools in Cross River State, Nigeria. Some teachers are engaged in trading more than their professional responsibilities. Some of them are combining full-time post-graduate studies in universities with their teaching jobs. Some teachers exhibit nonchalant attitude towards students' academic achievement and pay less attention to students' discipline. All these are indicators of lack of commitment among teachers.

Employee commitment is the degree to which a worker identifies with his work organization, its goals and objectives and the willingness to remain in the organization (Akpan, 2013). Thus, teachers' commitment is the strength of teachers' identification with and involvement in the school organization. It can be viewed as the dedication that teachers believe or perceive towards particular work and the job they carry out in the school.

Abdulla and Ramay (2011) refers to commitment as the focus and the desire of attachment of an employee to a certain task, his work or organization. Commitment can further be defined as identification with the values and goals of the organization, willingness to exert effort on behalf of the organization and commitment to stay in the organization 
(Mowday, Steers \& Porter, 1992). Allen and Meyer (1990) and Meyer and Allen (1991) identified three forms of commitment which are tools to measure institutional commitment. These are affective commitment, continuance commitment and normative commitment. Affective commitment deals with the attachment of a teacher with the school organization and its goals and objectives. It is affected by job characteristics (Morrow, 1993) and more concerned with intrinsic factors than extrinsic factors (Akpan, 2013). Continuance commitment deals with the concern of teachers on the cost associated with leaving the teaching profession and the lack of alternative employment opportunities. Normative commitment deals with teachers' loyalty and obligation to remain in the teaching job. Thus, commitment to organization is compatible with commitment to profession (Rahamn \& Hanagiah, 2002). Although these components of organizational commitment may differ, they have a similar impart on employees' (teachers') decision to either remain and continue or discontinue their employment with the organization (Akpan, 2013).

Various work-related variables influence institutional commitment of secondary school teachers. Three of such factors are staff development, working conditions and motivation of teachers. Staff training and development can have considerable influence on teachers' commitment and productivity. Alabi (2011) states that acquiring teachers' services, developing their skills, motivating them to high levels of performance and ensuring that they continue to maintain their commitment to the organization are essential to achieving school organizational objectives. Staff development is associated with the general improvement of the teachers in terms of attitude to work, behavior, skills and improved job performance. It enhances teachers' commitment. In Cross River State, teachers in secondary schools are not provided with adequate opportunities for training and retraining programmes (in-service education) to improve their knowledge and skills for effective job performance. Nkanu (2000) and Ogunkunle (2000) posit that inadequate provision for staff training and development in educational institutions could reduce their enthusiasm in the teaching profession and this could affect their morale, attitude to work and commitment. Therefore, staff development is an indispensable technique for motivating teachers to be committed to their professional duties and the school organization. Staff training gives teachers opportunities for self- improvement and development to meet the challenges and requirement of new equipment and technologies of performing a task. (Mensah, 2012).

Working condition is another factor that can enhance or hinder teachers' commitment. The physical conditions under which teachers carry out their work have been linked up with their institutional commitment. The physical working conditions involve the quality of the physical environment in which teachers work and include things like lighting, temperature conditions, ventilation, noise level, spacious classroom, good maintenance of facilities and library resources. All these affect the work environment and shape teachers' attitudes either positively or negatively towards the work. Thus, when the physical conditions in the work place are undesirable, employees tend to focus their attention on these problems and when these happen productivity suffers a great deal due to lack of commitment. In addition to the physical working conditions is the rewarding system for teachers in the State. The secondary school teachers are not well remunerated and their promotions are not regular and this could affect their level of commitment. A good reward plan for workers motivates them to perform their job better and this promotes high commitment. In the teaching profession, commitment of teachers is a function of the motivational factors they enjoy (Ahiauzu, Diepreye \& Onwuchekwa, 2011).

Research findings have shown that workers can only put in their best and be committed to their organization when their needs are satisfied and they are motivated. Denga (1996) reports that workers, whose needs, goals and aspirations are thwarted by the organization, develop feelings of low self-worth, become apathetic, disinterested, frustrated and tend to withhold self-commitment to the work. Thus, the way human resources of secondary schools are managed can influence their feelings and interest towards their job and commitment to the institution. In effective schools where teachers are well managed, they can be spurred to hard work, and will become enthusiastic in the pursuance of institutional objectives. Unfortunately, in Cross River State, secondary school teachers are subjected to work under conditions where there is few or no office facilities; where classrooms are overcrowded with students; where promotion, payment of salaries and other entitlements are unduly delayed; where teachers are inadequately motivated, and where there is inadequate provision for in-service training of teachers. Working under such deplorable conditions, the morale of teachers could sag (Akpan, 2008). This could result in lack of commitment to work and the institution.

A lot of researches have been carried out in the western world on the impact of work-related factors on organizational commitment of employees. But little or no research has been done in this area in the education sector in Nigeria, particularly in Cross River State. Although previous researches by Oredein (2006) and Akpan (2013) showed that transformational leadership, school climate, job security and job satisfaction significantly correlated with institutional commitment of teachers, the two studies did not consider staff development, motivation and working conditions as determinants of workers' commitment and organizational commitment was studied as a complete unit. Hence, the need for this study. In the present study, the components of institutional commitment (affective, continuance and normative) are studied in relation to the work-related variables. 


\section{Literature Review}

Researches on work-related factors such as staff development, working conditions and motivation have revealed that these factors enhance employees' commitment and productivity. Investment in human capital such as training is positively related to organizational performance. This means that training is expected to reduce turnover and increase employee commitment which will result in longer employment duration (Owoyemi, Shadare, Ayim \& Badejo, 2012). Thus, training is a key component of organizational process that can be used to secure work-force commitment. Arthur (1994) stated that human resource management practices suggest that workers' commitment will increase organizational effectiveness by creating a condition whereby workers become highly motivated, committed and involved in the organizational activities aimed at achieving organizational goals. In a study conducted by Owoyemi, Shadare, Ayim and Badejo (2012), it was found that training increased employees' commitment. This means that skill training improves employees' commitment. This finding was in agreement with an earlier work by Bulut and Culha (2010) who discovered in their study that all dimensions of training (access to training, motivation to training, benefits from training and support for training) positively affected employee commitment. This means that the more training is given the higher the level of employees' commitment to the organization. This finding is in accordance with existing literature that training is not only a valuable means of improving employees' knowledge and skills, but also a means of achieving higher employees' commitment to the organization (Barrrett \& O'connell, 2001). In a related study, Somers (1995) reported that affective commitment is the most consistent predictors of organizational commitment which is a sole predictor of turnover and absenteeism. Similarly, Alabi (2011) in her study found that teacher development and motivation significantly predicted teachers productivity. The researcher recommended that teachers need to acquire more knowledge through in-service training such as seminars, conferences and regular workshops in order to improve their competencies, productivity and commitment. Thus, teachers need to attend training programs for capacity development. Staff development is associated with the general improvement of teachers in terms of behavior, attitude, commitment, skills, knowledge, perception and in the performance of their duties (Adeogun, 2006).

Bartlett's (2001) study in USA revealed a strong relationship between four training variables and affective commitment, but a weak relationship with continuance commitment. Similarly, Ahmad and Baker's (2003) study showed a significant correlation between five training variables and affective commitment. But for continuance commitment, the study revealed a significant correlation with two of the training variables (training environment and perceived training benefits). In contrast to the research finding of Ahmad and Baker (2003), Al-Emadi and Marquardt (2007) in a study in the Qatar petrochemical industry found a positive correlation between perceived training benefits and both affective and continuance commitment. In a study conducted by Newman, Thanacoody and Hui (2011), it was found that there was a strong relationship between training variables (perceived availability of training, supervision support for training, co-worker support for training) and affective commitment. Perceived availability of training was also found to be significantly related with continuance commitment. This finding suggests that workers who have positive views of availability of training opportunities will continue to remain in the organization for fear of losing the training opportunities that leaving the job may incur (Newman et.al 2011).

Working condition is another factor that can impact organizational commitment. Research findings have shown that working conditions including physical environment and reward system influence employees' commitment. In a study conducted by Vanaki and Vagharseyyedin (2009) on organizational commitment, work environment conditions and life satisfaction among Iranian nurses, it was found that there was a significant positive relationship between work environment conditions and affective organizational commitment. This finding suggests that a comprehensive programme to improve the work conditions of Iranian nurses could enhance their organizational commitment. In a related study in Pakistan by Abdullah and Muhammad (2011), it was also found that work environment had a significant relationship with organizational commitment. This finding depicts that a healthy and friendly work environment can enhance an employee's commitment towards his/her work and the organization. Low performing employees are committed and comfortable in less/non-threatening environment, whereas high performing employees need a challenging environment (Steers, 1977). Therefore, organizations need to promote social activities so that friendly relations can improve between the employees and in turn, their commitment towards the organization excels (Kirmizi \& Deniz, 2009). Durotola (1999) in a study discovered a significant relationship between physical work environment and teachers' commitment to institutional tasks. Also, administrative work environment was found to be significantly related with teachers' commitment and performance. It could be deduced from these findings that teachers' institutional commitment is a function of many variables which include provision of adequate facilities, teachers' morale and the reward associated with workers performance. This finding is supported by the work of Ukaegbu (2000) who studied working conditions and employee commitment in indigenous private manufacturing firms in Nigeria. The result of the study showed that their workers were dissatisfied with 
the extrinsic and equity factors of their work which were stronger predictors of employee commitment than their intrinsic/responsibility component.

McGuire and Mclaren (2009) studied the impact of physical environment on employee commitment in call centers and the result of the study showed that employee well-being mediates the relationship between physical environment and employee commitment. This means that conducive and favorable working conditions can affect employee sense of wellbeing and thus, generate higher level of employee commitment. Therefore, it is important for employers to create good working conditions that can enhance workers' commitment. This finding is supported by the work of Danish, Ramzan and Ahmad (2013) who reported in their study that work environment had a significant positive association with organizational commitment, but an insignificant association was found between organizational support and organizational commitment. These findings support the assumption that working conditions and organizational support help to enhance organizational commitment of workers. Thus, a facilitative and appropriate work environment boosts up the commitment and productivity level of employees. In support of this, Cecunc (2004) in a study reported that for an organization to improve employee commitment, the organization must provide favorable physical working conditions, attractive rewards and recognition, ensure a cordial and friendly relations and control hazards in the work environment. A well design work environment will increase the organizational commitment and motivation level of employees and it ultimately enhances the outcomes (Brenner, 2004).

Researchers have also shown that work motivation has a significant influence on organizational commitment of employees (Meysam \& Ali, 2013; Parker, 2000; \& Arunkumar, 2013). Motivation is an energetic driving force in behavior. It induces employees to do their work with enthusiasm and be committed to it. Meyer and Allen (1991) pointed out that motivational factors which significantly predict organizational commitment among blue collar workers are promotion, satisfaction, job-characteristics, extrinsic and intrinsic rewards. Employees' productivity is highly related to their motivation levels and a higher level of organizational commitment. Motivation of workers can be viewed from two perspectives namely, intrinsic and extrinsic motivation. Thomas and Velthouse (1990) defined intrinsic motivation as positively valued experiences that an individual employee gets directly from the job and intrinsic factors that motivate workers to higher commitment are achievement, recognition, advancement, nature of work and challenging tasks. Extrinsic motivation involves factors which are peripheral to the job and include pay, working conditions, job-security and supervisor/ subordinate relations (Akpan 2008). Mullins (1996), reported that both intrinsic and extrinsic incentives significantly related to employees' commitment and loyalty to the organization. He suggested that managers of human resources should pay attention to both intrinsic and extrinsic incentives in work organization so as to motivate employees to higher level of commitment and productivity. This assertion was in agreement with the works of Akpekpe and Ejere (1997) and Udensi (2000) who found that the major determinants of job commitment were motivation and job satisfaction. Mensah (2011) in a study on motivation and job commitment among teachers in four selected Senior High Schools in the Ashanti Region of Ghana reported a significant positive correlation between motivation and commitment of teachers. This finding is in consonance with the research work of Choong, Wong, and Lau (2011) who reported a significant correlation between intrinsic motivation and the three components of organizational commitment namely, affective, continuance and normative. The result of the study further revealed that intrinsic motivation significantly predicted organizational commitment. In a related study by Meysan and Ali (2013) it was found that work motivation has a significant positive impact on organizational commitment of employees. The study further revealed that extrinsic motivation has more influence on organizational commitment of employees in comparison with intrinsic motivation. This finding suggests that institutional administrators should pay great attention to factors that positively impact work motivation. The study further showed that normative, affective and continuance commitment had the most to the least impact on organizational commitment of employees. This finding suggests that institutional or organizations' managers should provide suitable environment in work organizations to reinforce employees' commitment positively. Alabi (2011) reported in her study that teacher motivation and development significantly predicted teacher productivity. This finding shows that teachers need to be well motivated in terms of remuneration, status, recognition and training so that they can show more commitment to their job and the institution. Job security is an important motivational factor. If teachers know that their jobs are secured, they will be motivated to put in their best for the success of the school. Akpan (2013) in his study discovered that job security significantly predicted organizational commitment of university teachers. The researcher suggested that government and school authority should avoid actions that could lead to threat of job security as this could jeopardize teachers' sense of commitment.

\section{Conceptual Framework}

Based on the review of literature, the paper proposed a conceptual framework on the relationship between staff 
development, working conditions, motivation and institutional commitment of teachers. Researchers have revealed that training and development have a direct effect on employees' affective, continuance and normative commitment (Ahmad \& Baker, 2003; Al-Emadi \& Marquardt, 2007). This suggests that staff training induces organizational commitment of employees. Workers need favorable working conditions including attractive pay, job security, health and safety to be emotionally attached to the organization. This assertion is confirmed by the work of Khan, Nawaz, Aleen and Hamed (2012) who reported that working conditions, job safety and security have direct influences on employee commitment. This paper also encapsulates that work motivation has a strong relationship with the three components of institutional commitment namely, affective, continuance and normative commitment. Thus, the conceptual framework for this study is presented in figure I and it shows how the independent variables (staff development, working conditions and motivation) relate to the three components (affective, continuance and normative commitments) of the dependent variable i.e. institutional commitment of teachers.

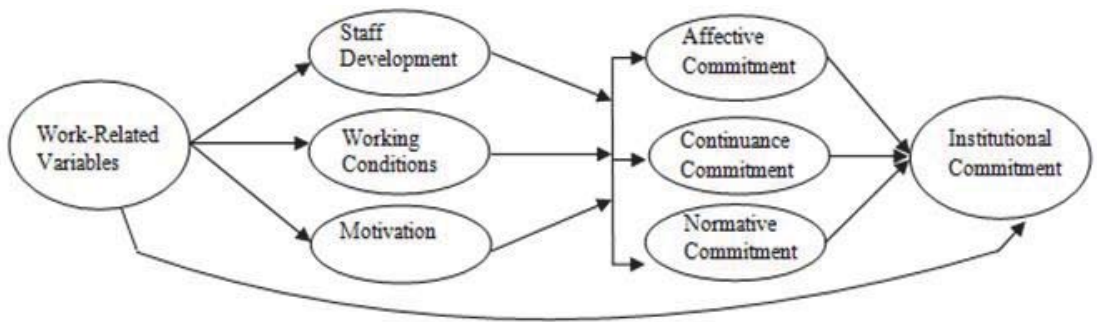

Fig. I: The conceptual model for the research variables and their relationships.

\section{Purpose of the Study}

The specific purpose of this study is to find out the extent to which

1. Staff development relates to affective, continuance and normative commitment of secondary school teachers.

2. Working conditions relate to affective, continuance and normative commitment of secondary school teachers.

3. Motivation relates to affective, continuance and normative commitment of secondary school teachers.

4. Work-related variables (staff development, working conditions and motivation) predict institutional commitment of secondary school teachers.

\section{Hypotheses}

$\mathrm{HO}_{1}$ : Staff development does not significantly relate to the affective, continuance and normative components of institutional commitment of secondary school teachers.

$\mathrm{HO}_{2}$ : Working conditions do not significantly relate to affective, continuance and normative components of institutional commitment of secondary school teachers.

$\mathrm{HO}_{3}$ : Motivation does not significantly relate to affective, continuance and normative components of institutional commitment of secondary school teachers.

$\mathrm{HO}_{4}$ : Work-related variables (staff development, working conditions, and motivation) do not significantly predict institutional commitment of secondary school teachers.

\section{Research Methodology}

\subsection{Research design}

The design adopted for this study was correlation design. This design is concerned with discovering or clarifying relationships among variables and it also helps researchers to predict future trends of variables. The design was appropriate for this study because the study was aimed at determining the degree of association between the independent and dependent variables of the study. 


\subsection{Participants}

The sample of the study consisted of 400 teachers selected from a population of 9,764 teachers using stratified random sampling technique. The bases for stratification were education zones of Cross River State (Ogoja,Ikom and Calabar zones) and school location (urban and rural). A breakdown of the sample revealed that $250(62.50 \%)$ teachers were males and $150(37.50 \%)$ were females.

\subsection{Instrument}

The instrument for data collection was a 5-point Likert type questionnaire and comprised three sections. Section A elicited personal information of the respondents such as gender, age and educational qualification. Section B was Work-Related Variables Questionnaire (WRVQ) developed by the researcher and it consisted of 15 items that measured staff development, working conditions and motivation. Five items were used to measure each sub-variable. Section $\mathrm{C}$ of the instrument was Organizational Commitment Scale (OCS) adapted from Meyer, Allen and Smith (1993) and it consisted of 18 items. Six items were used to measure each of the three components of institutional commitment (affective, continuance and normative). All the items in WRVQ and the OCS were measured using a 5-point response options which ranged from Strongly Disagree, Moderately Disagree, Uncertain to Agree and Strongly Agree. The instrument was trial tested by administrating it to 60 teachers who were not part of the main study. Cronbach Alpha reliability method was employed to ascertain the reliability (internal consistency) of the instrument. The WRVQ and the adapted OCS yielded reliability coefficients of 0.78 and 0.83 respectively. The instrument was administered on the respondents in their various schools with the help of three research assistants. All the 400 copies of the questionnaire administered were correctly filled and retrieved representing a response rate of $100 \%$.

\section{Data Analysis and Results}

The statistical tools for data analysis were Pearson Product Moment correlation and multiple regression statistics.

Table I: Correlation between the scores of staff development and Institutional commitment of teachers

\begin{tabular}{lccl}
\hline Variables & $\overline{\mathrm{X}}$ & $\mathrm{SD}$ & Pearson's ' $\mathrm{r}$ ' \\
\hline Staff Development & 11.19 & 3.24 & \\
Affective Commitment & 14.50 & 3.15 & $0.55^{*}$ \\
Continuance Commitment & 16.20 & 1.56 & $0.47{ }^{*}$ \\
Normative Commitment & 13.54 & 3.65 & $0.56^{*}$ \\
\hline \multicolumn{2}{c}{${ }^{*} \mathrm{P}<.05 ; \mathrm{df}=398 ;$ critical- $\mathrm{r}=0.098$} & &
\end{tabular}

The data on table I show that staff development is significantly related to affective commitment $(r=0.55)$, continuance commitment $(r=0.47)$, and normative commitment $(r=0.56)$ of secondary school teachers at alpha level of less than .05 with 398 degrees of freedom. Thus, the null hypothesis is rejected and the alternate hypothesis upheld. This means that staff development significantly correlated with affective, continuance, and normative components of institutional commitment of secondary school teachers. Therefore, the more teachers are exposed to training and development programs, the more committed they would be to their job and the institution.

Table 2: Correlation between the scores of working conditions and institutional commitment of teachers .

\begin{tabular}{lccl}
\hline & $\overline{\mathrm{X}}$ & $\mathrm{SD}$ & \\
Variables & 10.05 & 2.75 & \\
\hline Working conditions & 14.50 & 3.15 & 0.078 \\
Affective Commitment & 1.56 & 0.005 \\
Continuance Commitment & 16.20 & 3.65 & 0.034 \\
Normative Commitment & 13.54 & &
\end{tabular}

The data on Table 2 reveal that working conditions do not significantly correlate with affective commitment $(r=0.078)$, continuance commitment $(r=0.005)$ and normative commitment $(r=0.034)$ of secondary school teachers at .05 alpha level and 398 degrees of freedom. With this result the null hypothesis is therefore, upheld. 
Table 3: Correlation between the scores of motivation and institutional commitment of teachers .

\begin{tabular}{lcll}
\hline & $\overline{\mathrm{X}}$ & $\mathrm{SD}$ & Pearson's ' $\mathrm{r}$ ' \\
Variables & 17.15 & 2.35 & \\
\hline Motivation & 14.50 & 3.15 & $0.45^{*}$ \\
Affective Commitment & 16.20 & 1.56 & $0.66^{*}$ \\
Continuance Commitment & 16.54 & 3.65 & $0.52^{*}$ \\
Normative Commitment & 13.54 & &
\end{tabular}

Table 3 shows a significant positive correlation between motivation and affective commitment $(r=0.45)$, continuance commitment $(r=0.66)$, and normative commitment $(r=0.52)$ at alpha level of less than .05 with 398 degrees of freedom. This means increase in teachers' motivation will enhance affective commitment, continuance commitment and normative commitment of teachers. With this result, the null hypothesis is rejected and the alternate hypothesis is therefore upheld. This means that motivation is significantly related to affective, continuance and normative components of institutional commitment of secondary school teachers.

Table 4: Summary of multiple regression of work-related variables on institutional commitment of teachers.

\begin{tabular}{|c|c|c|c|c|}
\hline $\begin{array}{l}\text { Multiple R } \\
\text { Multiple R2 } \\
\text { Adjusted R2 } \\
\text { Standard Error } \\
\end{array}$ & $\begin{array}{l}= \\
= \\
= \\
=\end{array}$ & $\begin{array}{c}0.534 \\
0.487 \\
0.305 \\
11.320 \\
\end{array}$ & & \\
\hline Source of variance & SS & df & MS & $\mathrm{F}$ \\
\hline $\begin{array}{l}\text { Regression } \\
\text { Residual } \\
\text { Total }\end{array}$ & $\begin{array}{r}41494.65 \\
639124.20 \\
680614.85\end{array}$ & $\begin{array}{c}3 \\
396 \\
399\end{array}$ & $\begin{array}{c}13831.55 \\
1613.35\end{array}$ & $8.57^{*}$ \\
\hline
\end{tabular}

Table 4 shows the results of multiple regressions of the three work-related variables against institutional commitment of teachers. The results indicate that multiple $\mathrm{R}$ is 0.534 with the multiple R-squared being 0.487 . This depicts that $48.70 \%$ of the variable in the prediction of institutional commitment is accounted for by the work-related variables (staff development, working conditions and motivation). The coefficient of multiple regressions of 0.534 shows that there is a significant positive relationship between the joint predictor variables and institutional commitment. The result of analysis of variance gives an F-value of 8.57. This was found to be greater than the table F-value of 2.39 needed for significance at .05 level of significance with 3 and 396 degrees of freedom. This means that staff development, working conditions and motivation jointly and significantly predict institutional commitment of secondary school teachers. The relative contributions of staff development, working conditions and motivation to the prediction of institutional commitment of teachers are presented on Table 5.

Table 5: Relative contributions of the work-related variables to institutional commitment of secondary school teachers

\begin{tabular}{llll}
\hline Variables & Beta & T-value & Sig. T \\
\hline Staff development & 0.290 & $2.618^{*}$ & $\mathrm{P}<.05$ \\
Working conditions & 0.120 & 1.225 & $\mathrm{P}>.05$ \\
Motivation & 0.320 & $3.515^{*}$ & $\mathrm{P}<.05$ \\
\hline
\end{tabular}

Table 5 shows that the highest Beta-value is for motivation followed by staff development and working conditions having the least. The results also indicate that motivation has the highest T-value of 3.515 followed by staff development with Tvalue of 2.618. These values are found to be significant at .05 alpha level. Thus, motivation and staff development in that order make significant contributions to institutional commitment of secondary school teachers while working conditions with T-value of 1.225 and alpha level of greater than 0.05 does not.

\section{Discussion of Findings}

The finding of the study reveals that staff development significantly correlates with affective, continuance and normative components of teachers' commitment in secondary schools. The positive nature of the correlation coefficients show that 
the more training is given, the higher the level of teachers' commitment to their institutions. This finding suggests that provision for teachers' training/development enhances their emotional attachment to the school organization, their desire to remain in the teaching profession and improves their loyalty and obligation to their institutions. Thus, training/development is not only a strategy for improving teachers' skills, knowledge and attitude, but also a viable means of achieving teachers' commitment. The possible explanation for this finding is that training/development helps the teachers to be more committed to their institutions and to perform better on their jobs. This finding is in agreement with the works of Bartlett (2001) and Ahmed and Baker (2003) who discovered in their studies significant correlations between training and affective commitment. Similarly, the finding of this study is also in agreement with the research findings of AlEmadi and Marquardt (2007) who reported a significant relationship between training benefits and both affective and continuance commitment. Although, the impact of staff development on normative commitment has not been widely reported, this study has proved that training /development of teachers significantly correlated with normative commitment. Therefore, staff development enhances institutional commitment of teachers.

The study also reveals that there is no significant correlation between working conditions and affective, continuance and normative components of institutional commitment of teachers. This finding could be attributed to the fact that teachers' working conditions are not good enough to enhance their commitment. When the working conditions in schools are undesirable, teachers tend to focus their attention on these problems and when these happen productivity suffers a great deal due to lack of commitment. This finding is supported by Denga's (1996) assertion that workers whose needs, goals and aspirations are thwarted by the organizations develop feelings of low self-worth, become apathetic, disinterested, frustrated and tend to withhold self-commitment to the work. The finding is also in consonance with the research finding of Ukaegbu (2000) who reported a non-significant correlation between working conditions and employee commitment. The study showed that workers were dissatisfied with the extrinsic and equity factors of their work which were stronger predictors of employee commitment than their intrinsic/responsibility component. However, the present research finding is in contrast with the research reports of Cecunc (2004), McGuire and Mclaren (2009) and Danish, Ramzan and Ahmad (2013) who discovered in their studies significant correlations between working conditions and organizational commitment.

Another finding of this study showed that motivation significantly correlated with affective, continuance and normative components of institutional commitment of teachers. This could be attributed to the fact that motivation induces teachers to do their work with enthusiasm and be committed to it. The finding is in consonance with the works of Akpekpe and Ejere (1997), Udensi (2000) and Mensah (2012) who reported significant positive correlations between motivation and commitment of teachers. The research finding of Choong, Wong and Lau (2011) also lent credence to the present finding. They found a significant correlation between motivation and affective, continuance and normative components of organizational commitment. The study also revealed that the correlation between motivation and continuance commitment was strongest, followed by normative commitment and affective commitment in that order. The possible explanation to this finding is that although, continuance commitment is not an organizationally beneficial attitude, motivation will enhance teachers' willingness to remain in the teaching profession because of lack of other employment opportunities and the cost associated with leaving the job. This finding is in contrast with the work of Meysan and Ali (2013) who reported that normative, affective and continuance commitment had the most to the least impact on organizational commitment.

The study shows that the work-related variables (staff development, working conditions and motivation) significantly predict institutional commitment of teachers. This depict that institutional commitment of teachers does not happen by chance. The finding shows that motivation is a more potent contributor to the prediction while working conditions do not. The finding could be attributed to the fact that both intrinsic motivation and extrinsic motivation improve teachers' commitment. Thus, motivation is an important variable in teachers' commitment. This finding agrees with the work of Meyer and Allen (1991) who reported that motivation through promotion, job satisfaction, intrinsic and extrinsic rewards promote commitment. The study also establishes the fact that staff development is a contributor to the prediction of institutional commitment of teachers. The explanation for this is that staff development is associated with the general improvement of teachers in terms of attitude to work, behavior, skills and improved job performance. Another explanation to this finding is that perhaps the state government has seen the need to effectively involve teachers in training and retraining programs and refresher courses. These programmes boost teachers' morale and hence, their commitment. The finding of this study is in consonance with the research finding of Alabi (2011) who discovered that motivation and staff development are significant predictors of teachers' productivity and commitment. 


\section{Implications for Research and Practice}

The research findings have serious implications for the management of secondary Schools in Nigeria and Cross River State in particular. Staff training/development and motivation have the potentials to influence teachers' behavior such as commitment within the school organization. Institutional commitment and its three components namely, affective, continuance and normative commitment are considered to be attitudinal consequences of staff development and motivational levels of teachers. Thus, highly committed workforce always leads an organization to success. Training and development as well as motivation can enhance or induce teachers' sense of all components of institutional commitment, while working conditions may mot. Therefore educational managers and school administrators can acquire knowledge from the findings of this study that institutional commitment of teachers in secondary schools can be improved through adequate motivation and exposure of teachers to in-service training and other staff development programmes. Hence, staff development and motivation are two important work-related variables that can enhance teachers' commitment. This study provides school administrators with the knowledge that relates staff development, working conditions and motivation to teachers' commitment in secondary schools. This study will also provide valuable literature to researchers for further researches in this area.

\section{Recommendations}

This paper therefore recommends that:

School administrators and government should make adequate provision for staff development programmes and teachers should be encouraged to participate in such programmes to increase and update their knowledge and skills. The training will help them to have better understanding of school operations, classroom management and how to use modern technologies (e.g. ICT tools) for effective teaching. The existing training and retraining programmes which take place once in a year should be redesigned to meet teacher contemporary needs for effective job performance. The training will boost teachers' morale and enhance their institutional commitment.

Good working conditions should be provided for teachers to encourage them to stay on the job and be committed to their professional responsibilities. Facilitative physical working environment should be provided for teachers as well as appropriate and equity reward system to attract qualified teachers. This will make them to be psychologically attached to the institutions, remain on the job and be loyal to the institution. This will increase productivity as a result of high commitment.

Teachers should be optimally motivated through incentives that can capture their interest on the job. These should involve both monetary and non-monetary incentives. When the needs of teachers are satisfied, they would be enthusiastic to put in their best for the success of the school and would be committed to the vision, goals and objectives of the school. Motivation is a key factor in organizational commitment and therefore, should be taken seriously by both government and school administrators.

\section{Conclusion}

The conclusion that can be drawn from this study is that staff development and motivation have significant positive correlations with affective, continuance and normative commitment of teachers in secondary schools. These findings depict that the more the motivation of teachers, the higher their institutional commitment. Similarly, the more teachers are exposed to training and re-training and other staff development programmes, the higher their commitment. It is also concluded that staff development, working conditions and motivation jointly and significantly predict institutional commitment of teachers. Also, there is a significant difference in the relative contributions of staff development, working conditions and motivation with motivation being the most potent contributor followed by staff development. Working conditions do not significantly contribute to the prediction of secondary school teachers' commitment. It can be deduced that teachers who are involved in staff development programmes regularly and are adequately motivated are expected to exhibit a high sense of institutional commitment.

\section{References}

Abdullah \& Ramay, M. I. (2011). Antecedents of organizational commitment of banking sector employees in Pakistan. Serbian Journal of Management. 7 (1), 89-102.

Adeogun, A. A. (2006). Training and experience as predictors of teachers' productivity in secondary schools in Nigeria. International 
Journal of Educational Management. 4. 38 - 49.

Ahiauzu, L. U., Diejoriye, F. \& Onwuchekcva, C. A. (2011). Relationship between motivational factors and teachers' performance on the job in Ogba/Egbema/Ndoni Local Government Area of Rivers State, Nigeria. Mediterranean Journal of Social Sciences. 2 (5), 2326.

Ahmad, K. Z. \& Bakar, R. A. (2003). The association between training and organizational commitment among white collar workers in Malaysia. International Journal of training and Development. 7 (3) 166-185.

Akpan, C. P. (2008). Human resources management and commitment to duty among academic staff of higher institutions in Cross River State, Nigeria. South African Journal of Education Leadership and Management. 1 (1), 53-64.

Akpan, C. P. (2013) Job security and job satisfaction as determinants of organizational commitment among university teachers in Cross River State, Nigeria. British Journal of Education. 1 (2), 82-93

Akpekpe, S. O. \& Ejere, E. S. I. (1997). Mastow's Hierarchy of needs theory for employee motivation in Nigeria: A case study of University of Benin. African Journal of Educational Management. 5, 4-14.

Alabi, C. O. (2011). Teacher personnel management as determinants of teacher productivity in Oyo Metropolis senior secondary schools. Pakistan Journal of Social Science. 8 (1), 39-42

Al-Emadi, M. A. S \& Marquardt, M. J (2007). Relationship between employees beliefs regarding training benefits and employees' organizational commit in a petroleum company in the State of Qatar. International Journal of Training and Development. 11 (1), 49-70.

Allen, N. J. \& Meyer, J. P. (1990). Antecedents of affective, continuance and normative commitment to organization. Journal of Occupational Psychology. 63, 1-18.

Arthur, J. B. (1994). Effects of human resource system on manufacturing performance and turnover. The Academy of Manufacturing Performance, 37 (3), 670-687.

Arunkumar, S. (2014). An empirical study: relationship between employee motivation, Satisfaction and Organizational Commitment. International Journal of Management and Business Research. 4 (2), 81-92.

Barrett, A. \& O'Connell, P. J. (2001). Does training generally work? The return to company training. Industrial and Labour relations Review, 54 (3), 647-662.

Bartlett, K. R. (2007). The relationship between training and organizational commitment: A study in the Wealth Care Field. Human Resource Development Quarterly. 12 (4), 335-352.

Brenner, P. (2004). Workers' physical surrounding, impact bottom line accounting. [Online] Available: http://www.smarts.pros.com (November 3, 2014)

Bulut C. \& Culha, O. (2010). The effects of organizational training on organizational commitment. International Journal of Training and Development, 14 (4), 309-322. [Online] Available: http://www.researchgate.net/ publication (July 5, 2014)

Cecunc, E. (2004). Improving employee productivity in regulating industries. New York: Academic Press.

Choong, Y., Wong, k. \& Lau, T. (2011). Intrinsic motivation and organizational commitment in the Malaysian private higher education institutions: An empirical study. Journal of Arts, Science and Commerce. 11 (4), 91-100. [Online] Available: http://www. reseachersworld.com. (July 10, 2014)

Danish, R. Q., Ramzan, S. \& Ahmad, F. (2013). Effect of perceived organizational support

and work environment on organizational commitment: Mediating role of self-monitoring. Advances in Economic and Business. 1 (4), 312317. [Online] Available: http://www.hrpub.org. (August 2, 2014)

Denga, D. I. (1996). Human engineering for high productivity in industrial and other work organizations. Calabar, Nigeria: Rapid Educational Publishers.

Durotola, A. O. (1999). Administrative environment and academic staff performance in Nigeria. African Journal of Development Studies. $1(1 \& 2), 63-67$.

Federal Republic of Nigeria (2013). National Policy on Education. Lagos, Nigeria: NERDC Press.

Khan, A. H., Nawaz, M. M., Aleem, M. \& Hamed, W. A. (2012). Impact of job satisfaction on employee performance: An empirical study of autonomous medical institutions of Pakistan. African Journal of Business Management. [Online] Available: http://www. academicjournal .org/AJBM. (May 7, 2014)

Kirmizi, A. \& Deniz, O. (2009). The organizational commitment of IT professionals in private banks. European and Mediterranean Conference on Information Systems, July, 13-14, 209.

Mcguire, D. \& Mclaren, L. (2009). The impact of physical environment on employee in call centers: the mediating role of employee. Well being. Team performance management,15 (1/2), 35-48. [Online] Available: www.emeraldinsight.com/journals.htm?article= 1775756 (June 12, 2014)

Mensah, K. W. (2012). Motivation and job commitment among teachers in four selected Senior High Schools in Ashanti region of Ghana. [Online] Available: http:/dspace.knwt.edu.ghi:8080/jspui/handle/123456789/4465. (July 3, 2014)

Meyer, J. P. \& Allen, A. J. (1991). A three component conceptualization of organizational commitment. Human Resource Management Review, 1: 64-89.

Meyer, J. P., Allen, A. J. \& Smith, C. A (1993). Commitment to organization and occupation: Extensions and Test of a three-component conceptualization. Journal of Applied Psychology. 78, 538-551.

Meysam, A. \& Ali, J. N. (2013) Work motivation and organizational commitment among Iranian employees. International Journal of Research in Organizational Behaviour and Human Resource Management. 1 (3), 1-12.

Morrow, P. C. (1993). The theory and measurement of work commitment. Greenwich, CT. JAI Press. 
Mowday, R. T, Porter, L. W \& Steers, R. M. (1997). Employee - organization Linkages: The Psychology of commitment, absenteeism and turnover. New York: Academic Press

Mullins L. J. (1996). Management and organizational behavior. London: Pitman.

Newman A., Thanacoody, R. \& Hui, W. (2011). The impact of employee perceptions of training on organizational commitment and turnover intentions: A study of multinationals in the Chinese service sector. International Journal of Human Resource Management. 22 (8), 1767-1787. [Online] Available: http://eprints.mdx.ac.uk/4706. (August 2, 2014)

Nkanu, B. o. (2000). The universal basic education: Implications for teacher training and retraining. International Journal of Basic and Life-Long Education. 1 (1\&2),323-329

Ogunkunle, R. A. (2000). The universal basic education. Quality mathematics teachers' availability as a necessity for success. International Journal of Basic and Life-Long Education. 1 (1\& 2), 363-370.

Oredein, A. O. (2006). Transformational leadership and school climate as determinants of secondary school teachers' institutional commitment in Ogun State Nigeria. Journal of Sociology and Education in Africa. 5 (1), 31-48.

Owoyemi, O. A., Shadare, O. A., Ayemi, F. C. \& Badejo, E. (2012) Investigating the effect of training on employees' commitment: An empirical study of a discount house in Nigeria. Asian Journal of Business and Management Sciences. 1 (11), 26-32.

Parker, S. K. (2000). From passive to proactive motivation: The importance of flexible role orientations and role breath self-efficacy. Applied Psychology: An International Review. 49, 447-469.

Rahman, N. M \& Hanafiah, M. H (2002).Commitment to organization versus commitment to profession: Conflict or compatibility? Journal Pengurusan. 21,77-94. [Online] Available: http://www.ukm.my/penerbit/jurus.htm (September 4, 2014)

Somers, M. J. (1995). Organizational commitment, turnover and absenteeism: An examination of direct and interaction effects. Journal of Organizational Behavior. 16 (1), 47-58. [Online] Available: onlinelibrary.wiley/doi/10.1002/job.4030160107/abstract. (June 17, 2014)

Steers, R. M. (1977). Antecedents and outcomes of organizational commitment. Administrative Science Quarterly, 22 (1), 46-56.

Thomas, K. W. \& Velthouse, B. A. (1990). Cognitive element of empowerment: An interpretive model of intrinsic motivation. Academy of Management Review. 15 (4), 666-81.

Udensi, J. K. (2000).Impact of welfare services on productivity of academic staff in colleges of education. In E. O Fagbamiye \& D. O. Durosaro (Eds.). Education and Productivity in Nigeria.(pp. 165-176). Ilorin, NAEAP.

Ukaegbu C. C. (2000).Working conditions and employee commitment in indigenous private manufacturing firms in Nigeria: Managing organizations for Industrial Development. Journal of Modern African Studies. 38 (2), 295-324

Vanaki, Z. \& Vagharseyyedin, S. A. (2009). Organizational commitment work environment and life satisfaction among Iranian nurses. [Online] Available: www.ncbi.nim.nih.gov./pubmed (July 8, 2014) 